\title{
PERAN PENYELENGGARA AIR MINUM DALAM MENINGKATKAN SISTEM PENYEDIAAN AIR MINUM
}

\author{
Nadia Khoirunnisa \\ Jurusan Teknik Lingkungan, Fakultas Arsitektur Lanskap dan Teknologi Lingkungan, \\ Universitas Trisakti, Jakarta, Indonesia
}

Email korespondensi: nadia08215039@std.trisakti.ac.id

\begin{abstract}
ABSTRAK
Salah satu instansi yang menyediakan air minum baik domestik maupun non domesti bagi masyarakatnya adalah Perusahaan Daerah Air Minum (PDAM). Pada tahun 2016, persentase cakupan pelayanan air layak minum di Indonesia melalui perpipaan sebesar 42,12\% (Kementerian PUPR, 2017). Melihat hal tersebut, salah satu tujuan berkelanjutan pada Sustainable Development Goals (SDGs) atau adalah target Universal 100.0.100 tahun 2030 yaitu akses pelayanan air bersih aman harus disalurkan ke masyarakat sebesar 100\% dengan $80 \%$ dengan perpipaan. Masih banyak di beberapa daerah kecil yang belum mendapatkan penyediaan air minum yang layak. Hal tersebut disebabkan terbatasnya air baku untuk dijadikan sumber air, tidak optimalnya Instalasi Pengolahan Air (IPA), pemasangan jaringan transmisi dan distribusi air bersih, belum adanya sumber dana PDAM sehingga PDAM sulit mengembangkan SPAM, serta adanya alternatif sumber air lain sehingga masyarakat tidak berlangganan PDAM. Selain itu, besarnya tingkat kehilangan air menyebabkan salah satu penyebab PDAM belum optimal. Karya tulis ini akan membahas mengenai peran PDAM dalam meningkatkan pelayanan air minum, diantaranya dengan segi kualitas air baku dan air bersih, kuantitas, kontinuitas air bersih yang harus terpenuhi selama 24 jam, memperbaiki sistem perpipaan agar mengurangi kehilangan air, memasang meteran air di setiap pelanggan, menoptimalkan kapasitas IPA, mengoptimalkan regulasi terkait pengolahan air sehingga air yang didistribusikan memenuhi standar air minum, mengoptimalkan debit air baku dan debit air ke daerah pelayanan, mendistribusikan air berdasarkan kepadatan penduduknya. Selain itu, perlu adanya peran pemerintah dalam mensosialisasikan kepada masyarakat agar dapat berlangganan ke PDAM.
\end{abstract}

Kata Kunci: perusahaan daerah air minum (PDAM); sistem penyediaan air minum (SPAM);cakupan pelayanan; distribusi air

\section{PENDAHULUAN}

Perusahaan Daerah Air Minum (PDAM) merupakan salah satu badan penyelenggara air minum yang bergerak dibidang jasa publik penyediaan air bersih milik pemerintah daerah (Novitri, 2014). Dalam menyelenggarakan sistem penyediaan air minum, peran PDAM untuk memberikan pelayanan kebutuhan air minum merupakan hal yang penting. Seperti yang kita ketahui, salah satu tujuan Sustainable Developement Goals (SDG'S), yaitu tersedianya akses air bersih pada masyarakat dengan target Universal akses air bersih harus terlayani $100 \%$ pada tahun 2030 dengan $80 \%$ terlayani melalui perpipaan.

Menurut Pekerjaan Umum dan Perumahan Rakyat (PUPR), PDAM yang bekerja pada tahun 2018 terdiri dari 374 PDAM dari total 391 PDAM yang ada di Indonesia. Berdasarkan golongan PDAM, PDAM yang berkinerja sehat sebanyak 223 PDAM (57\%), berkinerja kurang sehat sebesar 99 PDAM $(25 \%)$, berkinerja sakit sebanyak 52 PDAM (13\%) dan 17 PDAM (5\%). Pada tahun 2016, cakupan pelayanan air yang layak untuk diminum di Indonesia melalui sistem perpipaan sebesar 42,12\%. Tingkat kehilangan air pada jaringan distribusi secara keseluruhan adalah 32,10\%. Masih banyak di beberapa daerah kecil yang belum mendapatkan penyediaan air minum yang layak. Hal tersebut disebabkan terbatasnya air baku untuk dijadikan sumber air, tidak optimalnya Instalasi 
Pengolahan Air (IPA), pemasangan jaringan transmisi dan distribusi air bersih, belum adanya sumber dana PDAM sehingga PDAM sulit mengembangkan SPAM, serta adanya alternatif sumber air lain sehingga masyarakat tidak berlangganan PDAM. Berdasarkan hal tersebut, perlu adanya peran PDAM dalam meningkatkan pelayanan air minum dalam mencapai target SDGs. Tujuan dari penulisan karya ilmiah ini adalah sebagai rekomendasi dan bahan pertimbangan bagi PDAM dalam meningkatkan Sistem Penyediaan Air Minum.

\section{TINJAUAN PUSTAKA}

\section{Sistem Peyediaan Air Minum}

Sistem Penyadiaan Air Minum (SPAM) adalah penyedia air minum yang dilakukan oleh penyelenggara terkait untuk memenuhi kebutuhan masyarakat. Dalam menunjang sistem penyediaan air minum, aspek yang harus diperhatikan adalah aspek teknis dan non teknis (Permen PU No. 18/PRT/M/2007). Menurut Tri Joko, 2010 aspek teknis meliputi unit air baku, unit produksi, unit distribusi, unit pelayanan, dan unit pengelolaan. Sedangkan aspek non teknis meliputi kauangan, sosial dan institusi.

Seiring dengan peningkatan pertumbuhan penduduk, perkembangan segala fasilitas dan kegiatan juga akan meningkat sehingga kebutuhan air bersih yang diperlukan dalam menunjang kegiatan tersbeut (Nelwan, et al. 2013).

Air minum adalah air yang memenuhi persyaratan bagi sistem penyediaan air minum. Kebutuhan air yang yang meningkat dengan belum optimalna SPAM, maka diperlukan peningkatan SPAM dalam segi sistem fisik (teknik) dan non fisik (institusi terkait, manajemen, keuangan, peran masyarakat) (Adrian Dwi Putra, 2018).

Kualitas air bersih adalah salah satu parameter yang berhubungan dengan parameter fisik, kimia, dan mikrobiologis yang terdapat pada PerMenKes No. 492/MENKES/PER/IV/2010). Dalam mneingkatkan kualitas air, maka harus meningkatkan pelayanan air bersih dan meningkatkan pelayanan sanitasi lingkungan. (Yogi Haratnto, dkk). Kuantitas air bersih adalah jumlah air yang disediakan untuk memenuhi kebutuhan dasar air sehingga manusia dapat memperoleh air yang dibutuhkan dalam kegaiatannya. Kontinuitas air minum adalah air yang mengalir ke pelanggan secara terus menerus selama 24 jam pada musim kemarau atau musim penghujan sehingga masyarakat dapat memenuhi kebutuhan setiap waktu.

Menurut Elvina dan Rulli (2014), faktor-faktor yang dapat mempengaruhi distribusi pelayanan air bersih terdiri dari beberapa faktor, yaitu sebagai berikut.

1. Luas daerah pelayanan

2. Status ekonomi penduduk

3. Kepadatan penduduk (kepadatan tinggi akan lebih membutuhkan air)

4. Sumber dana dalam peningkatan prasarana air bersih

5. Topografi daerah pelayanan

6. Perbedaan jarak antara Instalasi Pengolahan Air (IPA) dengan wilayah pelayanan

7. Tarif pelayanan air bersih setiap bulannya

8. Kondisi sumber air bersih seperti kelerengan terhadap daerah pelayanan

Dalam memenuhi kebutuhan air minum, pemakaian air yang dipakai pelanggan tentunya berubah-ubah sesuai dengan kebutuhannya. Terdapat faktor-faktor yang mempengaruhi dalam pemakaian air di setiap daerah. Menurut Linsley-Franzin, 1991, faktor-faktor yang mempengaruhi tersebut adalah:

1. Iklim.

2. Karakteristik Populasi Penduduk.

3. Industri dan Komersil. 
4. Ukuran Kota.

5. Meter Air.

\section{STRATEGI MENINGKATKAN PENYEDIAAN AIR MINUM}

Menurut Elvina dan Rulli (2014), strategi dalam meningkatkan penyediaan air minum adalah sebagai berikut :

1. Kepadatan penduduk permukiman yang tinggi

a. Kepadatan penduduk yang rata sesuai dengan tata guna lahan, kenyamanan dalam bertinggal dan aturan yang terkait.

b. Kepadatan penduduk yang rata tidak akan adanya intensitas pengambilan air baku yang berlebihan.

2. Sumber dan alokasi dana

Alokasi dana yang dibutuhkan adalah untuk:

a. Meningkatkan jaringan pipa transmisi dan distribusi sampai ke pelanggan.

b. Meningkatan kapasitas produksi atau debit sumber air sesuai debit maksimum sumber air.

3. Jumlah sumber air sebagai prioritas penduduk

a. Melakukan konservasi berupa penghijauan di sekitar sumber air bersih PDAM.

b. Mengembangkan penampungan air seperti waduk untuk air hujan da memanfaatkannya apabila terjadi kekeringan sumber air

4. Debit sumber air baku dalam kebutuhan air sesuai dengan masing-masing daerah pelayanan

a. Menambahkan debit aliran air bersih dari sumber air PDAM ke daerah yang penduduknya tinggi

b. Mengoptimalkan debit sumber air bersih dengan menggunakan kapasitas produksi yang belum terpakai.

c. Mengoptimalkan kelebihan kapasitas produksi sumber air tanah pada daerah pelayanan di sekitar sumber air baku

PDAM berusaha melakukan kinerja yang optimal dalam menyediakan air, akan tetapi kualitas dan kuantitasnya terjamin dan sama dengan daerah lain yang dilayani. Ada beberapa PDAm yang tidak memenuhi regulasi terkait mengolah air minum. Terdapat patokan berupa kriteria teknis pelayanan air minum dengan sistem perpipaan, antara lain :

a. Air mengalir dan tersedia secara terus menerus selama 24 jam

b. Tekanan air yang sampai di pelanggan minimal sebesar 1,5-2 atm

c. Kualitas air harus sesuai dengan ketetapan standar yang telah ditentukan

Beberapa penelitian terdahulu yang berkaitan dengan penulisan ini adalah :

1. Novitri (2014) meneliti bahwa peran PDAM adalah dalam penyediaan air oleh PDAM, yaitu dalam segi kualitas air baku dan air bersih, kuantitas dan kontinuitas air bersih. Kualitas air yang mendapatkan permasalahan diantaranya air bahan baku telah tercemar oleh limbah tambang dan tingkat kekeruhan atau lumpur cukup tinggi. Selain itu air mengalir kerumah pelanggan tidak 24 jam setiap harinya dan terdapat pula kebocoran pipa dan kemacetan meter yang cukup tinggi.

2. Sasmita Arief Nugroho (2017) meneliti bahwa terdapat faktor penghambat dalam pelayanan air minum, yaitu adanya gangguan jaringan produksi menyebabkan kualitas air tidak stabil, adanya kebocoran pipa disribusi, kekurangan air baku dan sumber air baku pada saat masuk musim kemarau, dan kondisi topografi wilayah pelayanan yang berbukit-bukit mengakibatkan penyediaan air bersih di wilayah tersebut menjadi 
terhambat.

3. Agrifa Maser, dkk (2017) meneliti strategi PDAM dalam meningkatkan kualitas air bersih untuk menunjang pembangunan pembangunan di kota wisata batu. Strategi tersebut adalah meningkatan pelayanan air bersih bagi penduduk dengan cakupan minimal 80\% dengan mengembangkan kelembagaan sektor air bersih, meningkatkan pendapatan dan meningkatkan efisiensi serta memperoleh keuntungan dengan cara meningkatkan kuantitas dan kualitas pelayanan air bersih dan menjaga daya dukung lingkungan sekitar.

4. Ruli Utami dan Erma (2016) menyatakan kehilangan air dapat ditekan atau dikurangkan dengan menggunakan permodelan sistem dinamik, yaitu melakukan validasi dari data riil kehilangan air sehingga mendapatkan standar deviasi.

5. Erwin Ferdiansyah, dkk (2018) menunjukkan bahwa faktor dominan yang mempengaruhi distribusi air bersih di Kecamatan Baitussalam adalah luas wilayah yang akan dilayani oleh PDAM Tirta Mountala, dan alokasi dana peningkatan prasarana air bersih. Strategi penyediaan air bersih di desa rawan air bersih pada Kecamatan Baitussalam adalah menetapkan wilayah pelayanan oleh PDAM Tirta Mountala terhadap bangunan pengolahan air bersih, kemudian mengalokasikan dana peningkatan prasarana air bersih, meningkatkan debit sumber air besih.

\section{PENUTUP}

Pelayanan air minum di Indonesia pada tahun 2016 baru mencapai 45,12\%. Hal tersebut disebabkan oleh kinerja PDAM yang belum optimal. Berdasaran penulisan ini dapat disimpulkan bahwa peran PDAM dalam meningkatkan pelayanan air minum adalah dari segi kualitas air baku dan air bersih, kuantitas, kontinuitas air bersih yang harus terpenuhi selama 24 jam, memperbaiki sistem perpipaan agar mengurangi kehilangan air, memasang meteran air di setiap pelanggan, menoptimalkan kapasitas IPA, mengoptimalkan regulasi terkait pengolahan air sehingga air yang didistribusikan memenuhi standar air minum, mengoptimalkan debit air baku dan debit air ke daerah pelayanan, mendistribusikan air berdasarkan kepadatan penduduknya. Selain itu, perlu adanya peran pemerintah dalam mensosialisasikan kepada masyarakat agar dapat berlangganan ke PDAM. Rekomendasi yang dapat diberikan adalah kerjasama anatara pemerintah dengan masyarakat dalam sama-sama peningkatkan SPAM, kerjasama antar pemerintah agar alokasi dana sesuai dengan kebutuhan peningkatan SPAM.

\section{DAFTAR PUSTAKA}

Agustina, Dian Vitta. 2007. Analisa Kinerja Sistem Distribusi Air Bersih PDAM Kecamatan Banyumanik di Perumnas Banumanik. E-Journal Universitas Dipenogoro.

Astuti, Novitri. 2014. Penyediaan Air Bersih Oleh Perusahaan Daerah Air Minum (PDAM) Kota Sangatta, Kabupaten Kutai Timur. eJournal Administrasi Negara. 3(2): 678-689

Ferdiansyah, Erwin, dkk. 2018. Faktor Dominan dan Strategi Penyediaan Air Bersih di Desa Rawan Air Bersih Pada Kecamatan Baitussalam, Kabupaten Aceh Besar. Jurnal Teknis Sipil Universitas Syiah Kuala. 1(4): 2088-9321.

Joko, Tri. Unit Air Baku dalam Sistem Penyediaan Air Minum. - Edisi Pertama Yogyakarta; Graha Ilmu. 2010. ISBN : 978-979-756-596-1.

Kementrian Pekerja Umum dan perumahan Rakyat. 2017. Buku Kinerja PDAM. 
Hertanto, Yogi, dkk. 2010. Identifikasi Sumber dan beban Pencemar Domestik di DAS Ciliwung Segmen 4 Serta Upaya Penanggulangannya. Indonesian Journal of Urban and Environmental Technology. 5(4): 117-124

DOI : http://dx.doi.org/10.25105/urbanenvirotech.v5i4.682

Maser, Agrifa, dkk. 2017. Strategi PDAM Dalam Meningkatkan Kualitas Air Bersih Untuk Menunjang Pembangunan di Kota Wisata Batu. Jurnal Ilmu Sosial dan Ilmu Politik. 6(2): 2442-6962.

Nelwan F, Wuisan EM, Tanudjaja L. 2013. Perencanaan Jaringan Air Bersih Desa Kima Bajo Kecamatan Wori. Jurnal Sipil Statik. 1(10): 2337 - 6732.

DOI: https://ejournal.unsrat.ac.id/index.php/jss/article/view/2901/2452

Noviyanti, Elvina dan Setiawan, Rulli Pratiwi. 2014. Penyediaan Air Bersih Pda Kawasan Rawan Air Bersih di Pesisir Utara. 16(2): 116-132.

DOI : 10.14710/tataloka.16.2.116-132

Nugroho, Sasmita Arief. 2017. Peran Perusahaan Daerah Air Minum (PDAM) dalam Penyediaan Air Bersih di Kecamatan Balikpapan Utara, Kabupaten Balikpapan. eJournal Administrasi Negara. 5(2): 5732-5736.

PP.2015. Peraturan Pemerintah Republik Indonesia Nomor 122 Tahun 2015 tentang Sistem Penyediaan Air Minum.

Putra, Adrian Dwi, dkk. 2018. Perencanaan Bangunan Pengolahan Air Minum di Kecamatan Bekasi Timur, Kota Bekasi, Jawa Barat. Indonesian Journal of Urban and Environmental Technology. 2621-2048

DOI : http://dx.doi.org/10.25105/psnkb.v1i1.2900

Ruli Utami, Erma Suryani. 2016. Perencanaan Strategis Untuk Menekan Tingkat Kehilangan Air PDAM Surabaya dengan Sistem Dinamik. Jurnal IPTEK. 1(20):1411-7010.

DOI: https://doi.org/10.31284/j.iptek.2016.v20i1.15 